AIBR

Revista de Antropología

Iberoamericana

www.aibr.org

Volume 14

Number 3

September - December 2019

Pp. $491-514$

Madrid: Antropólogos

Iberoamericanos en Red.

ISSN: 1695-9752

E-ISSN: 1578-9705

\section{Paradoxes of gender: Women declining motherhood and fathers claiming their children's care and nurturance}

Paloma Fernández-Rasines, Mercedes Bogino Larrambebere

Department of Sociology and Social Work, School of Human and Social

Sciences, Public University of Navarre

Submitted: 11.25.2017

Accepted: 10.08.2018

Dol: 10.11156/aibr.140307e

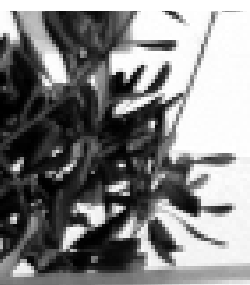




\section{ABSTRACT}

In this article our aim is to reveal an apparently paradoxical situation for normative sex/ gender patterns in relation to upbringing. The discussion focuses on to what extend women discharging from the cultural mandate of motherhood, and men meeting as fathers the process of day-to-day care, would raise the appearance of new models who travel with greater freedom and autonomy, beyond gender roles forced limits. In the first part, a review of specialized literature has provided us with the conceptual developments around women without offspring and/or free from it, as well as the construction of paternity by men who assume and claim their children's care and nurturance. In the second part, we show the results of our field work performed through in-depth interviews revealing the experiences of women and men from their standpoint as subjects declining motherhood and vindicating fatherhood respectively.

\section{KEY WORDS}

Motherhood, fatherhood, sex/gender, childless/childfree women, joint physical custody.

\section{PARADOJAS DE GÉNERO: MUJERES QUE DECLINAN LA MATERNIDAD Y PADRES QUE RECLAMAN LA CRIANZA $^{1}$}

\section{RESUMEN}

En este artículo queremos poner de manifiesto una situación paradójica para los patrones normativos de sexo/género con relación a la crianza. La discusión plantea en qué medida la fuga de mujeres del mandato cultural de la maternidad y la concurrencia de los hombres en los procesos de crianza suscitan la emergencia de modelos que nos hablan de figuras parentales que transitan con mayor libertad y autonomía, más allá de los límites impuestos por los roles de género. En primer lugar, una revisión de la literatura especializada nos ha provisto de los desarrollos conceptuales en torno a la posición social de las mujeres sin maternidad, así como de la construcción de la paternidad por parte de hombres que asumen y reivindican la crianza cotidiana de hijos e hijas. En segundo lugar, se muestran los resultados del trabajo de campo etnográfico realizado a través de entrevistas biográficas a mujeres y hombres que se posicionan como sujetos de la maternidad declinada y la paternidad asumida, respectivamente.

PALABRAS CLAVE

Maternidad, paternidad, sexo/género, no-maternidades, custodia compartida.

1. This article is the product from the $\mathrm{R}+\mathrm{D}+\mathrm{i}$ project: "La paradoja del deber/derecho sobre la crianza: padres custodios y mujeres sin maternidad" (The paradox of the duty/right to nurturance: fathers with custody and childfree mothers), led by José María Uribe from the Social Anthropology Research Group (GIAS) at the Public University of Navarre (UPNA) and funded by the Ministry of the Economy and Competition, CSO2012-39041-C02-02, (2013-2016). 


\section{Introduction}

In this paper, we aim to analyse an apparently paradoxical situation in the sex/gender system in relation to raising children in Spain over the last decade: coexistence of women who have distanced themselves from the cultural mandate of motherhood and men who claim greater visibility as care-providing fathers.

We talk about care in bringing up children, from the acceptance that English-speaking literature gives it as nurturance. This is how it appears in the modern construction of family as a key concept that implies something more than merely providing food and shelter for biological survival. Nurturance evokes emotional relationships that are based on cooperation, as opposed to competence, it is long-lasting and its practice is more collective than individual, eminently governed by morals and feelings (Collier, Rosaldo and Yanagisako, 1997). We also consider the mothering neologism with the intention of distinguishing motherhood from cultural practices around nurturance and caring, that might be performed by the biological mother or by other women and, on rare occasions, by the father (Chodorow, 1984; Marre and López, 2013).

With this proposal, we are focusing our study on the current convergence of two highly significant cultural changes: 1) non-procreation by women who distance themselves from hegemonic motherhood and 2) vindication of nurturance care by fathers in post-divorce situations.

Our aim justifies its relevance as women emerge who decide not to be mothers and men claim the right to care in nurturance which disrupts gender relationships, producing new social relationships that would infer unsexing parenting and problematizing family cohabitation (Rosenblum, 2012). The family model established by a father and a mother that live together, with heteronormative sexuality and the result of biogenetic procreation $^{2}$, is being questioned as a reference in modern Western societies (Cadoret, 2011). New expressions of kinship in Western societies are bound to the consequences of an increase in separations and divorces that are shaping unprecedented family forms, plural motherhood as the result of biogenetic manipulation or same-sex parent families that bring about new scenarios and possibly paradoxical situations for gender orders (Segalen, 2012). As indicated by González Echevarría (2016: 47), current parenthood studies work from the confluence of crisis in the classic kin-

2. In this model of the two-parent family or intact family, "intensive motherhood" ideology prevails, characterised by the great investment of time, economic and emotional resources in nurturance that gives women the main responsibility and registers their qualities and habits as part of the female condition (Hays, 1998). 
ship theory and an ethnographic emergence that considers extreme variability when performing parental roles. We can situate this contribution along these lines.

In the first part, we tackle a literature review that, on the one hand, allows us to outline conceptual developments around the social position of childfree women and, on the other hand, the construction of new fatherhood by men who assume and vindicate daily nurturance of their children once the family or couple are no longer living together.

The second part will present results from ethnographic field work mainly carried out in Navarre through unstructured interviews with women and men who take the respective stances of declining motherhood and assuming fatherhood.

\section{Women who dissent and decline motherhood}

The emergence of women who are not mothers, for different reasons and circumstances, is thought to be a growing trend in modern Western societies (Esteve, Devolder and Domingo, 2016; Reher and Requena, 2018) ${ }^{3}$. Different theoretical interpretations have used meanings linked to relinquishment, freedom and guilt. The observed experiences have been classified along a continuum that runs from heteronomy to autonomy in decision-making, identifying these transitions on a timeline from traditional to modern.

Early social sciences research focused on the term "childless" emerged in the 70s. Later studies introduced the terms "childless by choice" or "childfree", emphasising the subject's capacity to choose not to procreate (Blackstone and Stewart, 2012; Donati, 2003). In this section, we will outline a journey through different theoretical approaches and ethnographic experiences regarding this phenomenon.

Some pioneering research, developed in Canada by Veerves (1972), studied what were later called postponers (Ireland, 1993). As such, they are understood to be heterosexual couples who put off having children. Veerves (1972) detected changes in the desires felt by people in four phases or points in time. The first phase is related to seeking fulfilment of certain priorities, such as studying, finding the right partner, a decent job, travelling and enjoying leisure time, affording a house and so on and so forth according to each person or couple's expectations. In this respect, moth-

3. Recent projects suggest that, in Spain, between $25 \%$ and $30 \%$ of women born in 1975 will not be mothers by the time they reach the age of 50, the point in demographics when each generation's offspring are accounted (Esteve, Devolder and Domingo, 2016). 
erhood and fatherhood are not conceived as either a priority or a concern, rather a projection for the future. In the next phase, they continue postponing motherhood and fatherhood temporarily, until a time when the couple might consider themselves better prepared for the event. According to Veerves (1972), the key lies in the third phase, when the couple start to consider the possibility of non-procreation and discussions arise on the advantages and disadvantages of settling on the vague desire for motherhood (and fatherhood). Finally, in the fourth phase, the desire turns into non-desire and it is assumed that they will not have offspring, although in most cases - the author concludes - this decision is not taken explicitly, but rather identified subsequently.

Faced with this interpretation that combines what we might define as passive relinquishment and active relinquishment, we have the approach made by Movius (1976) that puts the focus, from another perspective, on constructing the identity of "childfree" women, by conceptualising what the author called "a life of their own". In this respect, Movius highlights some advantages of "childfree" women such as greater everyday mobility, less family commitments and more time to themselves, which all comes together as increased flexibility and the feeling of freedom. This approach has been echoed recently from some feminist ethnographers who reveal "the emergence of the phenomenon of non-mothers" (Ávila, 2013), in this case in Mexico City. A very specific question is raised here: Who are these women that, in a cultural context which values the maternal figure so highly, resist complying with gender mandates that de facto separate sexuality from reproduction and choose to live their lives without children? For Ávila (2013), these are numerically atypical women in Mexico, although symbolically significant because they express their resistance to a uniform, unambiguous or essentialist representation of the feminine identity bound to motherhood. In any case, returning to arguments in Movius (1976), we should not lose sight of the fact that the reasons for not having offspring are as complex and different as the reasons that bring on motherhood (and fatherhood) so it would be very difficult to perform an unambiguous reading of any option without considering the social, economic and cultural conditions that will help us understand (ir)rational decisions on motherhood in Spain (Álvarez, 2017).

If an exercise in empowerment and positive construction of childlessness could be appreciated in Movius (1976), in the study suggested by Morell (2000), from her biographical experience and from a post-structuralist feminist analysis, emphasis is put precisely on the feeling of guilt for some childfree women. In this way, Morell (2000) breaks down the cultural messages that childfree women receive which, the au- 
thor suggests, inform them of their inferior status as inadequate or incomplete subjects or rather, they are reminded that they lead a second-class life. In other words, women who are not mothers do not have the same privileges as women who decide to be mothers and, in the ideological context of the study by Morell (2000), it seems to be motherhood that turns women into morally superior beings and makes others inferior and invisible. Linking in with this approach, there is the proposal by Donati (2003) who investigates the interaction of the family, professional and emotional pathways of men and women who have passed their fertile age with no offspring. After analysing the unstructured interviews, the author maintains that non-procreation for a man and, even more so, for a woman arouses a certain "suspicion of abnormality". Along these same lines, Debest (2012: 43) points out that "a woman with no desire for motherhood is a potentially dangerous woman, she rejects what is assigned to her sex/gender and, consequently, she questions the sexual organisation of society."

In relation to this approach, and echoing the proposal by Gillespie (1999), we might talk about a scenario of two large groups of childless women: on the one hand, women who have actively chosen not to have offspring and, on the other hand, women that, on the contrary, have accepted other options that must be considered passive, as this depended on external circumstances or prior decisions derived from this subsequent infertility. We might put Hakim (2005) in a similar dichotomous framework, as she also identifies two groups of women according to their certainty regarding motherhood: women who are convinced that they do not want to be mothers and voluntarily freed from motherhood (voluntary childfree) and women who find themselves without children without having consciously made that decision (uncertain childless).

Moving beyond these initial, more polarised approaches that are schematic to a certain extent, Ireland (1993) outlines a classification defining three groups of women who are not mothers: 1) traditional women are characterised by seeking motherhood, but some physiological incapacity prevents this; 2) transition women include women who end up infertile as the consequence of delaying motherhood over time; and 3) transforming women are women who have actively chosen to be childfree. In this classification analysis, the author considers transforming women as pioneers, women that construct their identity from a personal, autonomous search, outside motherhood. In this respect, it might be perceived that these women wish to be free of the concerns and responsibilities implied by motherhood, they understand that the time and flexibility in 
their daily life is the result of their choice, giving them many possibilities for personal autonomy, creative work, political activism, professional development or leisure time.

In the new millennium, Gilbert (2008) defines four ideal types - in the Weberian sense - of female lifestyles. These styles represent a continuum, defining women as traditional to neotraditional, to modern and as far as post-modern, according to the importance awarded to work and the family. At one extreme, there are traditional women who are mothers of three or more children; their identity revolves around nurturance and caring for their offspring, and daily running of the home and domestic chores. They have experience in the workplace, but they prefer to take a career break - with the intention of going back to work later on - to perform active, exclusive and intensive motherhood. At the other end of the scale are post-modern women; these are childfree women, classified as highly individualist and career-oriented, with significant university qualifications and their identity revolves around their success in the workplace. In the middle of this continuum there are neotraditional and modern women representing women who feel tension between family and work life, attempting to balance demands from each world (domestic) public) and together they cover most women. Modern women are more focused on their profession, whilst neotraditionals prioritise their family life. Within this context of tension and social prejudice, mention should be made of the dialogue between Letherby and Williams (1999), based on their autobiographies and research interests, where they highlight not only the need to move beyond the stereotypical vision of childless women, as desperate, and childfree women as selfish and liberated, but also look in greater depth at the ambivalences and the social exclusion experienced by these women.

One line of research emerging recently from kinship anthropology proposes a historical and cross-cultural journey through the experiences, conceptualisations and relationships of persons or couples who do not have any offspring, insomuch as they remain hidden and invisible in the kinship system. From this perspective, Piella (2011) suggests the term "childless children" as a synonymous expression for the "childlessness and kinship" relationship and raises two fundamental questions: How are kinship relationships constructed when there are no offspring? What role do childless people play in their family networks? One of the author's answers indicates that, despite their undervalued position in the family network, childless people play an active role in their kinship relationships, either through inter-generational solidarity or shared care. Furthermore, as the author mentions, "the voluntary or involuntary absence of children 
does not imply deficient relationships or responsibilities within the sociocultural field of kinship" and, in this respect, "they act as transmitters of material, social and symbolic patrimony for the whole group" (Piella, 2011: 422 and 440).

In short, postponing and possibly declining procreation has represented an entire journey for women from different identity-based positions on a continuum between adapting to and breaking with the reproductive ideologies in force in each context. Below, we will see how men might also be configuring new gender identities by vindicating nurturance as fathers after marital breakdowns.

\section{A new ideology for responsible fatherhood}

There are many ways that a man might be included in the different contexts of masculine domination, but it is undeniable that most men are moving forwards very slowly and contributing increasing less to hegemonic masculinity (Lomas, 2003). In our cultural context, fathers have had the feeling that their authority would be weakened if they were emotionally implicated with their children. In this respect, responsible fatherhood is possibly acting as a launch pad for change and that also encourages us to think about the relationship between power and emotional life (Seidler, 2003).

Policies on fatherhood have been studied by social anthropology insomuch as they are instrumental from their very reason for being (Shore, 2010). In this respect, post-divorce fatherhood constitutes an important section of the study of father-child relationship transformation and what this implies for masculine identity. Simpson (1998) investigates divorce and its consequences in the United Kingdom through an ethnographic approach and working from interviews with families and professionals carried out in the late 80 s and early 90s. This author emphasises that changes taking place in families have been accompanied by a paternity ideology that is emerging to project positive images of masculinity and fatherhood itself, understood as responsible fatherhood.

Consequently, we can ask ourselves if the regulatory changes that are taking place in family law might be responding to economic policy decisions. There is little wonder that in 1991, the British Child Support Act 1991 emerged to replace the rhetoric of parental rights with talk of responsibilities. This highlights the need to ensure coparenting through cooperation between parents after divorce. It is supposed that the measures implanted in this respect were going to mean that fathers without custody would find the chance to develop a more active role in their children's 
lives. Derived from this, it was to be expected that the State could off-load primary care for single-parent families led by women who maintained the legitimate children of men classified as disaffected or directly absent fathers. It is possible to infer that the forecast for this derivative has acted, at least partially, as motivation to design what would become the new regulations.

Following on from this argument, it could be said that the new ideology for fatherhood owes a great deal to an individualist model of responsibility concerning nurturance and care in childhood. It seems that the children's development is the ultimate and, also, exclusive responsibility of father and mother as legal entities. We will see that part of the field work carried out for this article with the fathers reflects this idea.

Martial (2016) has recently led a compilation of works that, from social anthropology and demographics, analyse fatherhood after marital breakups in France and in Spain. Some of these studies are based on ethnographic experiences over the last few years and almost a decade since the legislation was implanted in France on promoting the legal measure of post-divorce joint physical custody/shared residence 4 . In this country, from 2002 onwards, the divorce reform law attributed joint parental authority to both parents and, at the same time, established the joint physical custody/shared residence measure to promote day-to-day living together and make it possible for each parent to live with their children. Data from 2007 indicated that $15 \%$ of minors lived in joint physical custody/ shared residence after parental break up processes although it was appreciated that this percentage had increased in subsequent years, also as a result of requests to modify prior measures that had given exclusive custody to the mother.

In Spain, the 2005 divorce reform law eliminated the breakup cause while introducing the possibility of awarding joint custody for dependent minors. As indicated by Fernández-Rasines (2016), from then on, we can appreciate the ideological influence of individualisation of parenthood. This might be due to progressive recognition of individual responsibility in parental policies that appears bound to the phenomenon of "demarriage", from the French démarriage, understood to be the

4. From the outset, post-divorce coparenting or shared residence in France took the term 'alternating custody' (garde alternée). In turn, terms commonly used in Spain have come from the English-speaking world and allude to joint custody, joint physical custody or shared residence. These terms encompass very wide-ranging social and legal situations that share joint responsibility for offspring, as well as sharing residence times and spaces between parents. For more details on the regulations, jurisprudence and its cultural application, please read Fernández-Rasines, 2017. 
trend towards making legal procedures more agile both for binding and breaking up partnerships, something which is already becoming a cultural trend in influential contexts such as France and the Englishspeaking world.

The measure, popularly known 'joint physical custody' (custodia compartida in Spain), is applied in the best interest of the minor, calling on children's right for their father and mother to provide responsible shelter, independently of the conjugal situation in force. Nevertheless, we can state that the Spanish reform that boosted the measures leading to encouraging post-divorce coparenting is in line with a new paternity ideology. This is what happens to the extent that the legislative developments and jurisprudence dictated for the cases of families have been implanted over the last few years in a cultural system where emerging parental configurations coexist and overlap with the most traditional forms of complementarity in gender relations (Fernández-Rasines, 2017).

However, regardless of the de jure situation of conjugal agreements and their modifications, it is interesting for us to shed some light on the real role that fathers and mothers play in daily life when they actually carry out this post-divorce sharing and rotation of authority, responsibility and custody. The aforementioned compilation by Martial (2016) looks at an ethnographic study carried out with blended families after conjugal breakup processes in Catalonia. In this study, Roigé (2016) focusses his attention on the relevance of the daily role of grandmothers and grandfathers in the lives of these families. In a previous publication, Riogé (2012) talked about the post-divorce extension or broadening of families. The author analysed the redefinition of fatherhood in this type of family situations around three questions: the new father figure who does not live with the mother, the figure of the stepfather or mother's new partner and the figure of the grandparents. In this way, it might be appreciated that what happens in practice is a long way from individualisation of parental responsibilities.

Within this same family constellation concept, Jociles and Villaamil (2008) conclude that post-divorce construction of fatherhood and motherhood involves mutual repercussion of practices and symbolic representations. This study, based on interviews with fathers and mothers after marital separation in the Madrid Region, indicates that the construction or deconstruction of the father's post-divorce role, as well as the symbolic position occupied by the father without custody, depends on interaction with other figures such as the mother's new partner or the stepfather and also the relationship between siblings. 


\section{Methodology}

In this paper, we are presenting results from qualitative research mainly run in the metropolitan area of Pamplona/Iruña. We have used the participant observation from a previous ethnographic experience to insert the biographic methodological strategy using in-depth interviews.

Between 2013 and 2016, 21 interviews were carried out with childfree women in the city of Pamplona/Iruña, mainly using snowball sampling. In parallel, we reached out to new respondents who publicly expressed their non-motherhood on social media in the cities of Bilbao, Barcelona and Madrid. For this contribution, we selected accounts from 6 key respondents. This refers to profiles of women who decide not to be mothers and, also, who have gone through processes of separation in their own relationships or are daughters of divorce in their original families. These are women who we understand to have declined the cultural mandate of motherhood.

In 2016, twelve interviews took place featuring men and women with dependent children following a separation or divorce. For this contribution, we have selected results relating to data provided by the 6 interviews with men who are claiming their position as fathers in the usual nurturance processes. The interviews took place in a previously agreed one-toone encounter during the second semester of 2016. The interviewees were sourced in two main ways: law firms being consulted for these issues and the mediation service in Navarre. Some additional cases also emerged through trusted networks.

To put our ethnographic work into context, it is relevant to provide some data on Navarre relating to divorce with dependent children and the effect of joint physical custody. In 2014, Navarre presented a rate of 2.1 marriages dissolved for every thousand inhabitants. The overall rate for Spain was 2.3 (INE, 2015). The dissolution rate has remained quite stable over the last decade. However, the percentage of joint physical custody cases has varied between 10 and $20 \%$. According to data from 2015, Navarre has the highest percentage of mutually consented separations and divorce, totaling $83.3 \%$ of its cases. More than half of the dissolutions involved couples who had been married for more than 10 years. There were dependent children in $55 \%$ of the breakups. Compared to other Regions, after Catalonia, Balearic Islands, Valencian Community and Aragon, Navarre stands fifth with $26.6 \%$ incidence of joint physical custody or shared residence according to the percentage of divorces with dependent children. The average in Spain is $24.4 \%$, and the highest figures are found in Catalonia with 40.5\% (Flaquer, Moreno and Cano, 2016). 
The field work analysis is presented below, structured into two parts: the first compiles voices of women who decline motherhood and the second, voices of men who take the stance of post-divorce fathers.

\section{Women who seek out a place outside motherhood}

The new trend in voluntarily childfree women is considered a population group that has barely been studied (Shapiro, 2014) and "it is surprising how little debate this elicits" (Esteve, Devolder y Domingo, 2016). They are perceived as study subjects who are difficult to access and, occasionally, "hidden and invisible" (Morell, 2004). Openly identifying yourself as childfree, as some of the interviewees do, means going against cultural gender mandates (Ávila, 2013). In particular, most women being interviewed would fit the "post-modern women" profile, and their decisions over the course of their lives are an "active choice" to remain childfree and, in this respect, they are "transforming women" within the sex/gender system (Debest, 2013; Gilbert, 2008; Gillespie, 1999).

The group of women being interviewed is noticeably diverse in aspects such as age, professional profiles and their work situation. In this respect, the age of the respondents varies from 33 to 65 years old and in terms of jobs, we find that two are unemployed (artist and biologist), one defines herself as an entrepreneur and another as a freelancer who works in her own small business (psychologist and journalist), one is a civil servant and another a factory operator and trade unionist (historian and social worker). Instead, we find greater homogeneity in terms of level of education, nationality or ethnic status and sexual orientation. All the women interviewed have university and post-graduate qualifications except for one who, despite not having any official qualifications, studied "economics, one year of engineering and then Fine Art." Concerning their geographic origin and sexual orientation, most of the women being interviewed are white, European and heterosexual, except for one who defines herself as a "sexual immigrant" and a lesbian, because at the end of the day she migrated "for love" whilst also seeking a "cultural change".

At the time of the interview, three of the women were single (two live with their heterosexual partner and one with her lesbian partner), one is a widow and the other divorced (they live alone with cats or dogs) and one of the women was in the process of separating from her (heterosexual) partner. All the women who were interviewed currently live in cities, but their lives have taken them from a village to a city, from one city to another or from one country to another. 
The analysis in this article lies mainly in the perceptions and ideas that the women being interviewed bestow on motherhood, the reasons that they identify throughout their lives to decide not to have offspring and the meanings that they express concerning their non-motherhood experiences.

In this study, as the women recount their experiences, they give the impression of building their identity, constantly moving and detached from motherhood. For these reasons, they consider that they have to be more creative because they don't have "their own place" in terms that "all of society is structured around being a mother" and "if you step outside the norm, you have to be creative." In this respect, motherhood is conceived as a social norm, an unquestionable social mandate, built as a natural and fixed identity that gives women a privileged status (Morell, 2004). In this way, "natural law" defines motherhood (Fassin, 2002). Therefore, women who choose not to have offspring are "denatured women" who challenge the dominant constructions of feminine identity and, at the same time, they have the chance to construct themselves (Letherby and Williams, 1999), as they state, with scarce social reference points. So, as one of the interviewees indicated, "many things have to be deconstructed from non-motherhood".

In this process of seeking and reconstructing oneself, we find that some women perceive motherhood as the weight of the "cultural gender mandates" that resonates like a duty or a debt and others mention, to the contrary, that the "maternal mandate" (that of their own mother) stops them from thinking, desiring or projecting themselves as mothers. In other words, in our modern Western societies, there is rivalry between the cultural gender mandates by assigning motherhood to women and the maternal mandate, that of each mother, projecting non-motherhood in some cases and in others, strongly imposing motherhood on to their daughters. One respondent explains it like this, "I don't have children by maternal mandate... that powerful whisper of the frustrated mother prevented me, so that it was never an option." In this case, motherhood did not even exist as a desire and these women's discourse generally revolves around non-desire rather than the vague desire for motherhood. One of them says she has "never had a hankering for motherhood." These women with no desire for motherhood question the difference between the sexes according to which fatherhood is bound by culture and parentage and, on the contrary, motherhood is associated with nature and biological reproduction. Consequently, by following this logic, it could be said that non-motherhood symbolically lies in the world of culture (Fassin, 2002). 
These women's accounts concerning the different decisions they make throughout their lives are complex and open to change, in a context where the intensive motherhood ideology is the norm. In this respect, it comes as no surprise that motherhood also crops up today as an option among lesbian couples, they have "the right to be a mother, although their emotional-sexual relations do not include reproductive sexuality" (Imaz, 2016: 416). One of the interviewees narrates her ambivalence regarding lesbian motherhood, "I said yes, but then no... I blew hot and cold." This lesbian couple considered motherhood, they talked about it with people they knew and friends, they asked a lawyer for advice and they thought about alternatives such as adoption or artificial insemination. In the end, time went by and the couple split up before taking their lesbian parenting project to the next level. Another of the women interviewed, in a heterosexual couple, travelled to London aged 31 years old to have an abortion, when it was still illegal in Spain. Her partner went with her and supported her decision, although he would have liked to have been a father. "Fortunately, he had children later on with another woman," says the respondent, who is happy for him and they are still friends. Another option that heterosexual couples consider if they do not wish to have children is a vasectomy, in other words surgery, in this case on the man's body. Furthermore, when women take the initiative and "make up their own minds" to not become mothers, their partners generally accept and, in many cases, agree with the decision without causing major conflict.

The most frequently mentioned reasons for not becoming mothers include that all of them, in one way or another, value their everyday sense of freedom and autonomy. They consider that travelling, reading, writing, taking a stroll, going to the cinema or to concerts, to the mountains or to the beach are all activities that they enjoy, that fulfil them and to a certain extent, they do not want to have to give up or relinquish that freedom. On the contrary, they perceive mothering as a responsibility that, at the same time, becomes a threat to their individuality. In this respect, motherhood is perceived as a limitation, a burden that implies satisfying the needs of others and, consequently, a loss of time to have "their own life" (Peterson, 2015).

Instead of explaining the future of non-motherhood by means of social circumstances, external factors or socio-demographic determinants, most of our interviewees stress that the reason is more personal, it is a decision made up of small decisions, with ambivalences and certainties. However, one of them recounts that "this imposed desire" for motherhood fades over the years. In general, they do not remember a specific day that 
they made the decision not to be a mother, nor do they identify it as a milestone or key event. It becomes diluted over time.

From these ethnographic fragments, we might understand that declining motherhood could be interpreted as an expression of the women's ability to challenge gender regulations by forging new identities outside motherhood, both in daily life and symbolically.

\section{Men who claim nurturance as post-divorce fathers}

The profiles of the respondents being interviewed for this paper represent cases of men who are fathers with relative heterogeneity in terms of location of rural/urban origins, socio-economic profile and migratory experience. On the other hand, they have in common that they come from two-parent family units where both ex-partners have had paid employment and the breakup occurred in the last five years. All the respondents were referred to the study as participants in coparenting models and post-divorce joint physical custody or shared parent-child residence, which is not stated legally in the same way in all cases.

In the first-level analysis, we wish to draw attention to the group of respondents depending on the chronology and the family cycle, their training and economic activity, their geographic and migratory references and on their cultures of separation and divorce.

As far as chronology and the family cycle are concerned, this refers to six men born between 1961 and 1978 who are aged between 38 and 55 years old in the ethnographic present. They all have either two or three children, aged between 3 and 18 years old, from partnerships between persons of a different sex. As far as the children's age is concerned, Solsona and Ajenjo (2017) conclude in their study carried out in the Barcelona law courts, that joint physical custody is given more frequently in rulings when minors are aged between 6 and 11 years old, and shared residence tends to decline from 12 years old. In this respect, our paper also compiles cases of teenagers who abandon the shared residence regime or make it more flexible, usually because of schoolwork and its implications, or seeking proximity and consistency with their peer groups.

In terms of education levels, five of these fathers report that they have taken further education, professional technician levels, diplomas and university degrees. This bias was also highlighted in previous studies carried out in Madrid (Muñoz, 2014) and Catalonia (Spijker and Solsona, 2012). Half of them chose masculine-related courses and careers, in the field of construction and engineering. The educational level that they report for their ex-partners seems to be equivalent or even higher in some cases. 
In terms of time spent on paid work, they have all worked constantly and full-time for most of their working lives, making social security contributions for between 17 and 22 years. Prior to the breakup, all cases lived together in homes where two adults were providers or received income for paid work ${ }^{5}$ (dual earners). However, it should be highlighted that the level of dedication to paid work for the mother and father during the marriage required a more in-depth analysis in each case. All the fathers state that their children are the result of pregnancy with their partners. None of the fathers asked for parental leave or unpaid leave for childcare. However, they report that their ex-partners used up all their maternity leave in each pregnancy and requested unpaid leave for childcare, whenever this was possible. In almost all cases, their ex-wives stopped working or reduced their paid work time during motherhood processes. In this respect, the study by Solsona and Ajenjo (2017: 1) affirms that "joint physical custody should be the logical sequence of an agreement that reflects an equal coparenting practice prior to the breakup, which is not true for the majority right now."

This set of respondents is diverse in terms of geographic and cultural reference points. In the group, we have one person from the Basquespeaking area who identifies as coming from the countryside. We should also highlight the migratory culture when defining these life experiences. Two of the respondents were international migrants with transnational family project development. One of these couples comprises two people with the same nationality, from a neighbouring European Union country. The other mixed couple were binational, with one person coming from a country with a very distant context to the European Union. In another two cases, national migration appears for education and career reasons for them or their parents.

As far as the demarriage culture (démarriage) is concerned, the ties with the mother of their children was their first marriage for all of them; and their divorce, their first breakup. Therefore, their children come from

5. The family model based on the dual-earner couple alludes to a reality that defines couples that come together in a relationship based on a love choice, regardless of whether or not it is a marriage, and each one makes an economic contribution to maintaining the home and children, if there are any. In the USA, this model seems to be gaining ground over the single breadwinner, usually male, dating back to the 1950s (Aronson and Gold, 2007). In the case of Spain, it was above all from the 1990s onwards that the transition took place towards the dual model due to the significant increase of women with formal paid employment. At the end of the millennium's first decade, the majority of Spanish homes made up of two people followed the dual earner model. However, in almost one third of these homes, the father is the only person who is economically active or apparently the provider (Castro-Martín and Seiz, 2014). 
a single relationship. Only two of them report that they are in a new relationship at the time of the interview. And as far as divorce culture is concerned, none of them have referred to their parents having separated or having any reference point for breakup in their family or surrounding environment. Our respondents do not belong to blended families from second or third marriages as occurred in Roigé's study (2012).

Having been referred by the family guidance and mediation services as examples of coparenting best practice, we can say that the fathers being interviewed are what Martial (2013) called "exemplary fathers". In all cases, the breakup was mutually agreed and the level of communication at the time of the interview was reported to be functional and, occasionally, cordial. Therefore, these are cases with no manifest conflict. We would like to highlight that, as it is not particularly common, these fathers' experience might be a reference point as pre- and post-divorce parental roles undergo changes.

At a second level of analysis, we might highlight the most relevant aspects on gender contracts relating to coparenting. One constant in the accounts refers to both father and mother doing paid work before the divorce. However, they do not do so in a balanced and interchangeable way. The provider-father and carer-mother roles prevail in 5 out the 6 cases. Despite this evidence, in just one of the cases, the respondent explicitly declares that his ex-wife spent more time with the children. After the divorce, the agreements mean that the time dedicated to nurturance remains shared and leans towards greater equilibrium in terms of dividing the time spent with each parent. In three cases, this was stated to be $50 \%$ of shared time. In the case of lower participation from the father, this is stated as one third of each month and half of the school holidays.

Aside from time distribution, it is significant that all the fathers interviewed declare that right now they work afternoon shifts or leave work at a time that is later than the usual time that children leave school in our context for pre-school and compulsory education. The information we collected does not clarify how the educating responsibility is managed in this key time slot.

Regarding decisions that were made regarding the type of custody for the sons or daughters, understood as relative to post-breakup residence, in most cases, a movement was seen towards alternating or shared residence. Two of the respondents mention that during the separation prior to the divorce, they went from an exclusively maternal custody model with agreed paternal visits to joint physical custody/shared residence. Regarding the initiative, two of the cases declared that the request 
for joint physical custody came from the father. None of the cases indicated that the proposal came unilaterally from the mother and in half the cases, the mother was initially reticent to begin joint custody. However, none of the cases had requested modifications in the divorce agreement to date, and they did not plan to do so in the near future. So, in all cases, the first divorce ruling is the agreement that prevails at the time of the interview. Let's say that, de jure, we have five cases of rulings involving agreements that are technically known as "custody for both parties" and one case of "single parent maternal custody". Based on practice, this designation does not explain much in itself.

In all the cases, it was after the separation and due to the divorce that a transition had been made towards a greater distribution of time actually spent, including living, with children. On paper, 4 out of the 6 cases state $50 \%$ distribution. There were two cases with one third of the time during the school year, which means 8 to 10 days per month, and $50 \%$ of the school holidays. In both cases, this is due to intensive working hours and afternoon shifts.

In terms of specifying day-to-day agreements, a general pattern can be appreciated that is weekly or fortnightly rotation of residence by the children. One of the cases indicated a transitional situation towards a type of shared custody, where the elder son was with the father and the younger son with the mother, although they occasionally alternated with both parents for two weeks at a time. It is the children that move between two homes in all cases and the most usual frequency is weekly or intra-weekly. One of the locations continues to be the family home, privately owned, or with a joint mortgage that was paid off or in the process of being paid off. The other home is a rented property, except in one of the cases where the ex-partner went to live with her parents.

Finally, in relation to external support and support from third parties, two cases reported an informal caregiver providing support during time slots that could not be conciliated. Another two cases indicate that their current partner or a friend might occasionally look after the children. In all cases, the children attended nursery school (0-3-year-old cycle). However, it is telling that no case refers to having used, or even having needed childcare services such as after-school clubs, 0-3-year-old nurseries or any other public or private specialised program for specialised childcare. In all cases, apart from the father and mother, the grandparents appear as emergency and first line support. The maternal grandparents are mentioned in all cases and the paternal grandparents in some cases. This aspect is a constant in Spain that has been clearly demonstrated. Along this same line, as mentioned by Fernández-Rasines (2016:125) and 
according to results from the Sociological Research Centre barometer, in 2014 , care for 3 year old fell to the mother in $82 \%$ of cases, with the grandmother as the second option with $7.5 \%$, ahead of the father in $4.8 \%$ of cases.

\section{Conclusions}

In this article, we have shed light on a paradox for the sex/gender system that reflects, on the one hand, the reality of women who decline motherhood whilst also claiming acknowledgement for this, and on the other hand, the situation of men who assume nurturance as fathers and even claim the rights and obligations of fatherhood.

On the one hand, the cultural context that endorses the intensive motherhood ideology turns mothers into morally superior women whilst conferring an inferior status on non-mothers. The experience of women with no offspring tells us about the capability to decide or choose a life outside of motherhood. Some research projects we consulted suggest how, occasionally, when there is a vague desire for motherhood, over time this can fade into non-desire. In this respect, it is also seen that the reasons for not having offspring are as complex and ambivalent as those that lead to motherhood or fatherhood.

The voices of the women being interviewed express that they have gone through a process of seeking and reconstructing their identity due to not being mothers with scarce social references, moving between adaptations to and ruptures in the gender and kinship system. Some of these women identify motherhood as a clearly intensive practice and they are not prepared to assume this cultural mandate that exalts the motherhood experience as a social merit. In other words, they perceive mothering as a responsibility that, at the same time, becomes a threat to their individuality. They vindicate the right to choose, as opposed to the duty to produce offspring, and autonomy in daily life by means of managing their own time and spaces, detached from nurturance. And from the experience of non-motherhood, they have to deconstruct a wide range of discourse and social practice that undermines their voice and place in the world because they are "not mothers".

On the other hand, post-divorce fatherhood seems to be the result of public policies and an ideology that emerges alongside to promote a positive image of masculinity and fatherhood. This new fatherhood ideology seems to respond to an individualistic model of responsibility for nurturance and daily care for children, a model that coexists with new intensive parenthood. This is reflected when analysing data from the interviews with 
fathers. In their discourse, fatherhood is mentioned and referred to as a responsibility. It is inferred that this parental responsibility is perceived as something that required commitment due to maintaining an exclusive and intensive nurturance activity that must be performed only by the father and the mother. In their accounts, they barely allude to institutional support or third parties. However, the data reveals that nurturance is supported, in this order, by maternal grandparents, paternal grandparents, sisters, informal caregivers "home help", and new partner or girlfriend. The analysis shows no explicit trace of institutional support for childcare, nor any possible claim or request for it.

Negotiated agreements for joint custody reveal a debate around the time dimension, related to the meaning of balance for daily periods, overnight stays, school and holiday time. Balance in the distribution of economic or food provision is directly linked to this. Ideal distribution is set at $50 \%$, as a goal to be achieved. There is less debate around shared residence for children who move between two homes, envisaged close to where they go to school and socialise in all cases.

The ex-partners of these men have not been active defenders of joint custody and, in some cases, they were reticent. This might be because distribution of direct care and time spent with their children was unequal before the divorce, although it has been balanced out by post-divorce agreements. Doubtlessly, these modifications can have a modelling or pedagogic effect on other types of families.

Throughout the text, we have seen women and men who dissent, by omission or by action respectively. Each person's experiences represent vanishing points for the sex/gender system. However, it is possible to appreciate that the ideologies bound to intensive motherhood and new fatherhood might lie behind the individualisation of parental responsibilities, when the ideal is shown to be respect and acknowledgement for autonomy in the decisions to have and raise children.

\section{References}

Álvarez, B. (2017). Las (ir)racionalidades de la maternidad en España: influencias del mercado laboral y las relaciones de género en las decisiones reproductivas. Doctoral Thesis, Departamento de Antropología Social y Cultural, Universitat Autònoma de Barcelona. Aronson, P. and Gold, S. (2007). Dual-Earner Couples. In Blackwell Encyclopedia of Sociology Online. G. Ritzer, Ed. Malden (Mass.): Blackwell Publishing.

Ávila, A. (2013). La emergencia del fenómeno de las mujeres no madres. In Parentescos en plural. M.E. Olavarría, Ed. México: Miguel Ángel Porrúa, UAM. 
Blackstone, A. and Stewart, M.D. (2012). Choosing to be childfree: Research on the decision not to parent. Sociology Compass, 6(9): 718-727.

Cadoret, A. (2011). La nature de la parenté. Quaderns de l'ICA, 27: 81-96.

Castro-Martín, T. and Seiz, M. (2014). La transformación de las familias en España desde una perspectiva socio-demográfica. VII Informe sobre exclusión y desarollo social en España. Madrid: Fundación Foessa.

Chodorow, N. (1984). El ejercicio de la maternidad: psicoanálisis y sociología de la maternidad y paternidad en la crianza de los hijos. Barcelona: Gedisa.

Collier, J.; Rosaldo, M. and Yanagisako, S. (1997). There a Family? New Anthropological Views. In The Gender Sexuality Reader: Culture, History, Political Economy. New York: Routledge.

Debest, C. (2013). Quand les sans-enfant volontaires questionnent les rôles parentaux contemporains. Annales de Demographie Historique, 125(1): 119-139.

Donati, P. (2003). La non-procréation : un écart à la norme. Informations sociales, 107: 44-51.

Esteve, A., Devolder, D. and Domingo, A. (2016). La infecundidad en España: tic-tac, tic-tac, tic-tac !!! Perspectives Demogràfiques, 1: 1-4.

Fassin, É. (2002). La nature de la maternité. Journal des anthropologues, 88-89(1): 103-122.

Fernández-Rasines, P. (2017). Sharing Child Custody: Co-Parenting After Divorce in Spain. Oñati Socio-Legal Series, 7(6): 1-18.

Fernández-Rasines, P. (2016). Parentalidad: leyes, normas y prácticas parentales. Quaderns-e de l'Institut Català d'Antropologia, 21(2): 119-134.

Flaquer, L.; Moreno, A. and Cano, T. (2016). Changing Family Models: Emerging New Opportunities for Fathers in Catalonia (Spain)? In Balancing Work and Family in a Changing Society: The Fathers' Perspective. I. Crespi y E. Ruspini, Eds. London: Palgrave Macmillan.

Gilbert, N. (2008). A Mother's Work: How Feminism, the Market, and Policy Shape Family Life. New Haven: Yale University Press.

Gillespie, R. (1999). Voluntary childlessness in the United Kingdom. Reproductive Health Matters, 7(13): 43-53.

González Echevarría, A. (2016). El alcance de las teorías sobre la parentalidad. La comparación transcultural como extensión de los modelos etnográficos. AIBR. Revista de Antropología Iberoamericana, 11(1): 33-57.

Hakim, C. (2005). Childlessness in Europe [Research Report to the Economic and Social Research Council (ESRC)].

Hays, S. (1998). Las contradicciones culturales de la maternidad. Barcelona: Paidós.

Imaz, E. (2016). ¿Rebiologización en las familias de elección? Lesbomaternidad y uso de tecnologías reproductivas. AIBR. Revista de Antropología Iberoamericana, 11(3): 405-418.

INE (2015). Estadística de Nulidades, Separaciones y Divorcios. Año 2014. Madrid, September 15 th.

Ireland, M. (1993). Reconceiving Women: Separating Motherhood from Female Identity No Title. New York: Guilford Press. 
Jociles, M.I. and Villaamil, F. (2008). Estrategias para evitar y/u obstacularizar la paternidad/ maternidad de los padrastros/madrastras en las familias reconstituidas. Revista mexicana de ciencias politicas y sociales, 204: 103-120.

Letherby, G. and Williams, C. (1999). Non-motherhood: Ambivalent autobiographies. Feminist Studies, 25(3): 719-728.

Lomas, C. (2003). Masculino, femenino y plural. In ¿Todos los hombres son iguales?: identidades masculinas y cambios sociales. C. Lomas, Comp. Barcelona: Paidós.

Marre, D. and López, C. (2013). Epílogo. Aportes para una antropología del maternaje. In Maternidades, procreación y crianza en transformación. C. López, D. Marre, y J. Bestard, Eds. Barcelona: Edicions Bellaterra.

Martial, A. (2016). Des pères "en solitaire" ? Ruptures conjugales et paternité contemporaine. Université de Provence, collection «Penser le genre».

Martial, A. (2013). Des pères « absents " aux pères « quotidiens " : représentations et discours sur la paternité dans l'après-divorce. Informations sociales, 2(176): 36-43.

Morell, C. (2004). Necesitar y encontrar el valor. Debate feminista, 29(15): 40-46.

Morell, C. (2000). Saying No: Women's Experiences with Reproductive Refusal. Feminism \& Psychology, 10(3): 313-322.

Movius, M. (1976). Voluntary Childlessness. The Ultimate Liberation. The Family Coordinator, 25(1): 57-63.

Muñoz, D. (2014). Por mis hijos lo que sea... o casi. Identidades de madres y padres que han vivido un divorcio. Papeles del CEIC, 2014/1(103): 1-30.

Peterson, H. (2015). Fifty shades of freedom. Voluntary childlessness as women's ultimate liberation. Women's Studies International Forum, 53: 182-191.

Piella, A. (2011). Tener o no tener... hijos. Una aproximación histórica y transcultural a la relación entre infecundidad y parentesco ('hijos sin hijos'). In ParentescoS: Modelos Culturales de Reproducción. J. Grau, D. Rodríguez, y H. Valenzuela, Eds. Barcelona: PPU.

Reher, D. and Requena, M. (2018). Childlessness in Twentieth-Century Spain: A Cohort Analysis for Women Born 1920-1969. European Journal of Population: 1-28.

Roigé, X. (2016). Nouvelles paternités, nouvelles grand-parentalités : divorce et relations entre générations. In Des pères "en solitaire »? Ruptures conjugales et paternité contemporaine. A. Martial, Ed. Université de Provence, collection « Penser le genre ».

Roigé, X. (2012). Un " élargissement » de la famille ? Parcours de pères divorcés et redéfinitions de la paternité à Barcelone. Ethnologie française, 42(1): 135-144.

Rosenblum, D. (2012). Unsex Mothering: Toward A New Culture of Parenting. Harvard Journal of Law \& Gender, 35.

Segalen, M. (2012). Être parents, être pères aujourd'hui. Ethnologie française, 42(1): 7-12.

Seidler, V.J. (2003). Transformando las masculinidades. En ¿Todos los hombres son iguales?: identidades masculinas y cambios sociales. C. Lomas, Comp. Barcelona: Paidós.

Shapiro, G. (2014). Voluntary childlessness: A critical review of the literature. Studies in the Maternal, 6(1): 1-15. 
Shore, C. (2010). La antropología y el estudio de la política pública: Reflexiones sobre la «formulación» de las políticas. Antípoda. Revista de Antropología y Arqueología, 10: 21-49.

Simpson, B. (1998). Changing families: An ethnographic approach to divorce and separation. Oxford: Berg.

Solsona, M. and Ajenjo, M. (2017). La custodia compartida: ¿un paso más hacia la igualdad de género? Perspectives Demogràfiques, 8: 1-4.

Spijker, J. and Solsona, M. (2012). Atlas of divorce and post-divorce indicators in Europe. Papers de demografia, 412:1-110.

Veerves, J.E. (1972). Factors in the incidence of childlessness in Canada: an analysis of census data. Social Biology, 19(3): 266-74. 